\title{
Profound "turn-off" effects of anionic polymers on the inhibitory activity of cationic polyallylamine in the prevention of silica scale
}

\author{
A. Spinthaki, A. Stathoulopoulou and K. D. Demadis* \\ Crystal Engineering, Growth and Design Laboratory, Department of Chemistry, \\ University of Crete, Voutes Campus, Crete, GR -71003, Greece \\ *E-mail: demadis@chemistry.uoc.gr
}

\begin{abstract}
Colloidal/amorphous silica $\left(\mathrm{SiO}_{2} \cdot n \mathrm{H}_{2} \mathrm{O}, n\right.$ is variable) is considered as the most undesirable inorganic precipitate that forms during various processes in silica-supersaturated industrial waters. In this paper we present how certain polymeric chemical additives can prevent silicic acid polymerization to form colloidal silica, which may lead to deposition onto industrial equipment. More specifically, stabilization of silicic acid is accomplished by using a cationic polymer, polyallylamine hydrochloride (PALAM), in supersaturated silica solutions (starting silica concentration in the form of silicate $500 \mathrm{ppm}$, or $8.3 \mathrm{mM}$ sodium orthosilicate, $\mathrm{Na}_{2} \mathrm{SiO}_{3} \cdot 5 \mathrm{H}_{2} \mathrm{O}$, expressed as $\mathrm{SiO}_{2}$ ) at $\mathrm{pH}=7$. PALAM is a linear homopolymer that carries one amine side functional group every two carbon atoms, so it becomes protonated at circumneutral $\mathrm{pH}$, rendering the molecule cationic. Its blends with anionic polymers such as carboxymethylinulin (CMI), poly(acrylamide-co-acrylic acid) (PAM-co-AA) and phosphonomethylated chitosan $(\mathrm{PCH})$ are also studied for their silica scale inhibition efficiency.
\end{abstract}

Key words: silicic acid stabilization, silica, inhibitors, deposits, water systems, inhibitors, polyallylamine, carboxymethylinulin, polymers.

Received: January 6, 2015.

doi: $\underline{10.17675 / 2305-6894-2015-4-1-085-095}$

\section{Introduction}

Water is the global fluid of choice for cooling purposes in industry because of its low cost, and high thermal capacity [1-6]. During its re-use, scaling and deposition can develop due to the high content of dissolved species [7]. The deposits that may appear depend on the specific water chemistry [8]. Among the water-, or steam-formed deposits colloidal silica $\left(\mathrm{SiO}_{2} \cdot n \mathrm{H}_{2} \mathrm{O}, n\right.$ is variable and dependents on hydration), a very persistent precipitate, is thought to be of the toughest to combat, as it can cause serious materials failure and operational shut-downs, Figure 1 [9]. 


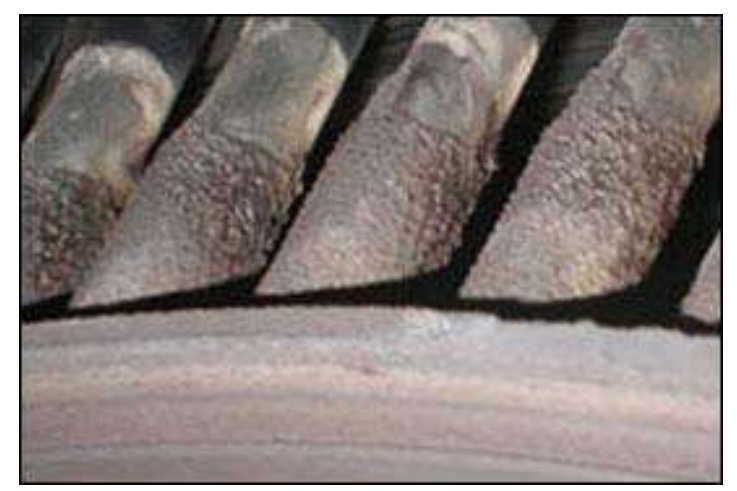

Figure 1. Amorphous silica deposits on steam turbines. Reproduced with permission from https://tofanhakim.wordpress.com.

Control of silica polycondensation, in principle, can be achieved by use of chemical additives [10] or capital-intensive water desilicification [11-15]. Unfortunately, traditional scale control methods (inhibition and crystal modification) applied to crystalline mineral salt precipitates [16], do not apply to silica because of its amorphous state [17]. Therefore, carefully designed inhibition approaches have to be implemented for controlling silica deposition. Increasing environmental concerns and discharge limitations have imposed additional challenges in treating process waters. Therefore, the discovery and successful application of chemical additives that have mild environmental impact has been the focus of several researchers [18-22].

In this paper we focus on use of "green" inhibitors silica scale inhibition, plus cost effectiveness, as PALAM is a rather economic additive compared to other "green" ones. This research is part of our on-going investigation on the discovery and application of scale inhibitors in industrial process waters [19-39].

In this work, we present the inhibiting effect of polyallylamine hydrochloride (PALAM), on the formation of amorphous silica starting from water-soluble sodium silicate. PALAM is a linear homopolymer of $\sim 15 \mathrm{KDa}$ molecular weight, which possesses a "tail" of a primary amine functional group (Figure 2). These amine moieties become protonated at circumneutral $\mathrm{pH}$, rendering the polymer cationic, and thus enabling interaction between cationic PALAM with negatively charged silicate. Multifunctional blends of PALAM with anionic polymers (see Figure 3) are also studied for their silica scale inhibition efficiency.

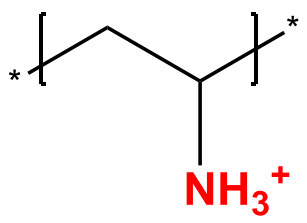

Figure 2. Schematic structure of polyallylamine hydrochloride (PALAM) in its cationic form, highlighted in red. 


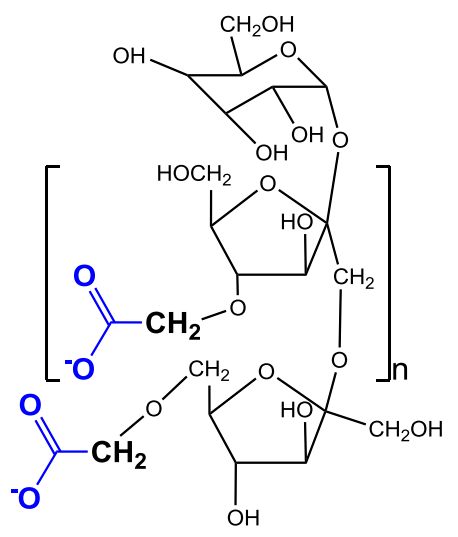

Carboxymethylinulin (CMI)<smiles>CC(C)(C)CC(CC(C)(C)CC(CC(C)(C)C)C(=O)[O-])C(N)=O</smiles>

Poly(acrylamide-co-acrylic acid) (PAM-co-AA)

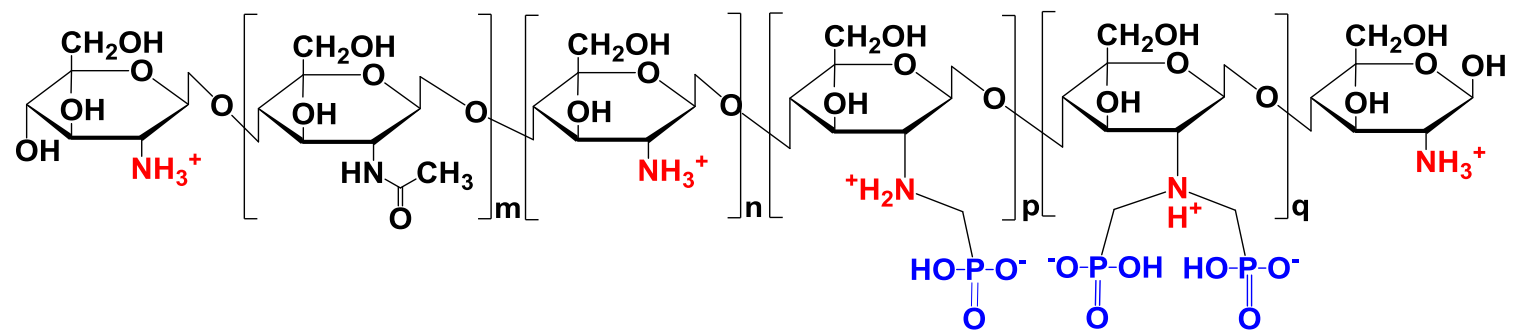

Phosphonomethylated chitosan $(\mathbf{P C H})$

Figure 3. Structures of the silica scale co-inhibitors used in this work. Cationic groups are highlighted in red, anionic ones in blue.

\section{Experimental Section}

\section{Instruments}

IR spectra were recorded on an FT-IR Perkin-Elmer FT 1760 instrument. The measurements of soluble silicic acid were carried out with a HACH 890 spectrophotometer from the Hach Co., Loveland, CO, U.S.A.

\section{Reagents and Chemicals}

Sodium silicate pentahydrate $\mathrm{Na}_{2} \mathrm{SiO}_{3} \cdot 5 \mathrm{H}_{2} \mathrm{O}$ and PALAM were purchased from SigmaAldrich. Ammonium molybdate $\left(\left(\mathrm{NH}_{4}\right)_{6} \mathrm{Mo}_{7} \mathrm{O}_{24} \cdot 4 \mathrm{H}_{2} \mathrm{O}\right)$ was obtained from Alfa-Aesar and oxalic acid $\left(\mathrm{H}_{2} \mathrm{C}_{2} \mathrm{O}_{4} \cdot 2 \mathrm{H}_{2} \mathrm{O}\right)$ from EM Science (Merck). Sodium hydroxide $(\mathrm{NaOH})$ and hydrochloric acid $(\mathrm{HCl}) 37 \%$ were purchased from Sigma-Aldrich. Deionized water from an ion-exchange resin was used for all experiments and stock preparations. This water was tested for molybdate-reactive silica (interference tests) and was found to contain negligible amounts.

\section{Preparation of Sodium Silicate Solutions ('Stock' Solutions)}

A solution containing silicate $\left(500 \mathrm{ppm}\right.$ as $\left.\mathrm{SiO}_{2}\right)$ was prepared by dissolving $4.08 \mathrm{~g}$ of $\mathrm{Na}_{2} \mathrm{SiO}_{3} \cdot 5 \mathrm{H}_{2} \mathrm{O}$ in $2 \mathrm{~L}$ of deionized water (a non-glass container must be used), followed by 
overnight rigorous stirring. Stock solutions of the additives in water (PALAM, CMI, PAMco-AA, PCH) were $1 \% \mathrm{w} / \mathrm{v}(10.000 \mathrm{ppm})$. The following solutions were prepared for the silicate spectrophotometric detection test: (a) An ammonium molybdate solution: $10 \mathrm{~g}$ of ammonium molybdate was dissolved in $100 \mathrm{~mL}$ of water, and its $\mathrm{pH}$ was adjusted between 7 and 8 with $\mathrm{NaOH}$ to avoid precipitation of ammonium molybdate. (b) A hydrochloric acid solution: one volume $37 \% \mathrm{HCl}$ was mixed with equal volume water. (c) An oxalic acid solution: $8.75 \mathrm{~g}$ of oxalic acid was dissolved in $100 \mathrm{~mL}$ of water. All solutions were kept in polyethylene containers (glass containers must be avoided to minimize $\mathrm{SiO}_{2}$ dissolution and silicate leaching into the test solutions). $\mathrm{HCl}$ and ammonium molybdate were kept in the fridge, while silica and oxalic acid solution were kept at room temperature.

\section{Silicic Acid Polycondensation Protocol (“Control” experiment)}

$100 \mathrm{~mL}$ from the $500 \mathrm{ppm}$ sodium silicate stock solution (see above) was placed in a polyethylene beaker and the initial $\mathrm{pH}$ was found to be 11.8. The $\mathrm{pH}$ is then adjusted to $7.00 \pm 0.1$ by addition of $\mathrm{HCl}$ and/or $\mathrm{NaOH}$, as needed (the change in the resulting volume was minor and did not affect any of the calculations). Then, the beaker was covered with plastic membrane and set aside without stirring. The solutions were checked for molybdate-reactive silica by the silicomolybdate method every 1 hour for the first 8 hours or after 24,48 , and 72 hours after the $\mathrm{pH}$ adjustment (see below). All experiments (control and in the presence of inhibitor and co-inhibitor) were treated in precisely the same way.

\section{Silicic Acid Polycondensation in Presence of PALAM and co-inhibitors}

$100 \mathrm{~mL}$ portions of the $500 \mathrm{ppm}$ sodium silicate stock solution (see above) were placed in polyethylene containers. In each container, different volumes of pure PALAM or PALAM and co-inhibitor (from the prepared $10.000 \mathrm{ppm}$ stock solutions) were added to achieve desirable concentration. After that, the same procedure as the "control" protocol was followed.

\section{Determination of Molybdate-Reactive Silica}

Molybdate-reactive silica (mainly mono- and some disilicic acid) was quantified using the well established silicomolybdate spectrophotometric method [40-45]. As in our previous studies [19-39], we used the "yellow molybdate" method (using a HACH DR/890 spectrophotometer) as follows: $2 \mathrm{~mL}$ from the working solution is filtered through a $0.45 \mu \mathrm{m}$ syringe filter and then diluted to $25 \mathrm{~mL}$ in a special cylindrical cell of $1 \mathrm{~cm}$ path length, made of quartz. Next, $1 \mathrm{~mL}$ of ammonium molybdate stock solution and $0.5 \mathrm{~mL}$ of $\mathrm{HCl}(1: 1$ dilution of the concentrated solution) are added to the sample cell, the solution is shaken well and left standing for $10 \mathrm{~min}$. Afterward $1 \mathrm{~mL}$ of oxalic acid solution is added and the cell contents are mixed well. The solution is set aside for $2 \mathrm{~min}$. The photometer is now set to "zero absorbance" using a sample of deionized water ("blank"). Finally, the sample absorbance is measured (at $452 \mathrm{~nm}$ ) and is expressed as "ppm $\mathrm{SiO}_{2}$ ". The detectable concentration range for this specific protocol is $6-75 \mathrm{ppm}$. To calculate the concentration in 
the original solution, an appropriate dilution factor $(\times 27.5 / 2)$ is applied. The basic working principal of the silicomolybdate test is that ammonium molybdate reacts only with monoand disilicic acid and any phosphate present and forms yellow-colored complexes. This reaction requires acidic environment in order to take place, and this is why the hydrochloric acid is added to the samples. It should be noted that colloidal silica does not participate in the reaction and thus does not affect the intensity of yellow color, which is proportional to the concentration of the reactive silica present in the sample experiment. Oxalic acid is added to destroy any molybdophosphoric acid formed, leaving the silicomolybdate complex intact, and thus eliminating any color interference from phosphates.

\section{Results and Discussion}

\section{Inhibitory activity results of PALAM}

Initially, PALAM was tested as silica scale inhibitor in "long term" experiments (up to 3 days). This is an important time frame for scale inhibitors, as it evaluates the ability of a certain inhibitor to prevent scale formation for a prolonged time period. Inhibitory activity results for PALAM (at concentrations 20, 40, 60, and $80 \mathrm{ppm}$ ) are presented in Table 1 and plotted in Figure 4.

Table 1. Silica inhibition measurements with PALAM (20, 40, 60 and $80 \mathrm{ppm})$ in long-term experiments (3 days).

\begin{tabular}{cccccc}
\hline \multirow{2}{*}{ Time (hours) } & \multicolumn{5}{c}{ PALAM concentration (in ppm) } \\
\cline { 2 - 6 } & control & $\mathbf{2 0}$ & $\mathbf{4 0}$ & $\mathbf{6 0}$ & $\mathbf{8 0}$ \\
\hline 24 & 202 & 327 & 268 & 248 & 223 \\
48 & 179 & 270 & 245 & 221 & 206 \\
72 & 160 & 246 & 252 & 217 & 193 \\
\hline
\end{tabular}

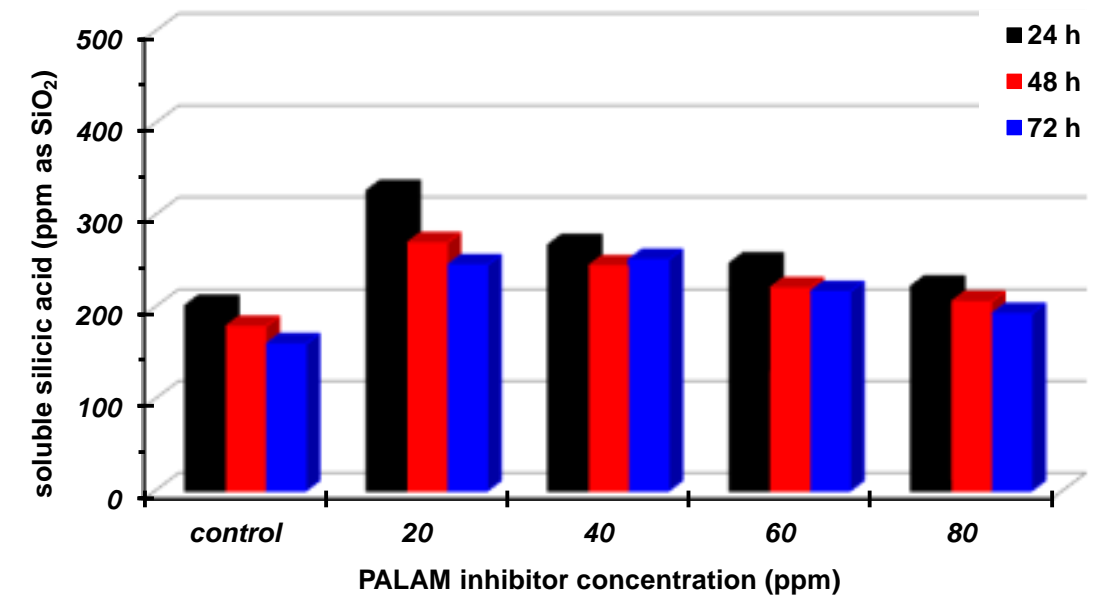

Figure 4. Silica inhibitory activity of PALAM in long-term (3 days) experiments. 
Based on these results, it appears that PALAM is active in silicic acid stabilization even at the "low" dosage of $20 \mathrm{ppm}$. Specifically, it stabilizes $125 \mathrm{ppm}$ (after $24 \mathrm{~h}$ ) above the control value, when present in the system at $20 \mathrm{ppm}$. Its inhibitory activity drops over time (as observed with almost all silica inhibitors studied so far), stabilizing $91 \mathrm{ppm}$ (after $48 \mathrm{~h}$ ) and $86 \mathrm{ppm}$ silicic acid above the control.

An additional point that warrants some attention is that upon PALAM concentration increase, its inhibitory activity is reduced. This is clearly shown in Figure 5, where a virtually linear drop in activity is observed at $24 \mathrm{~h}, 48 \mathrm{~h}$, and $72 \mathrm{~h}$ measurements.

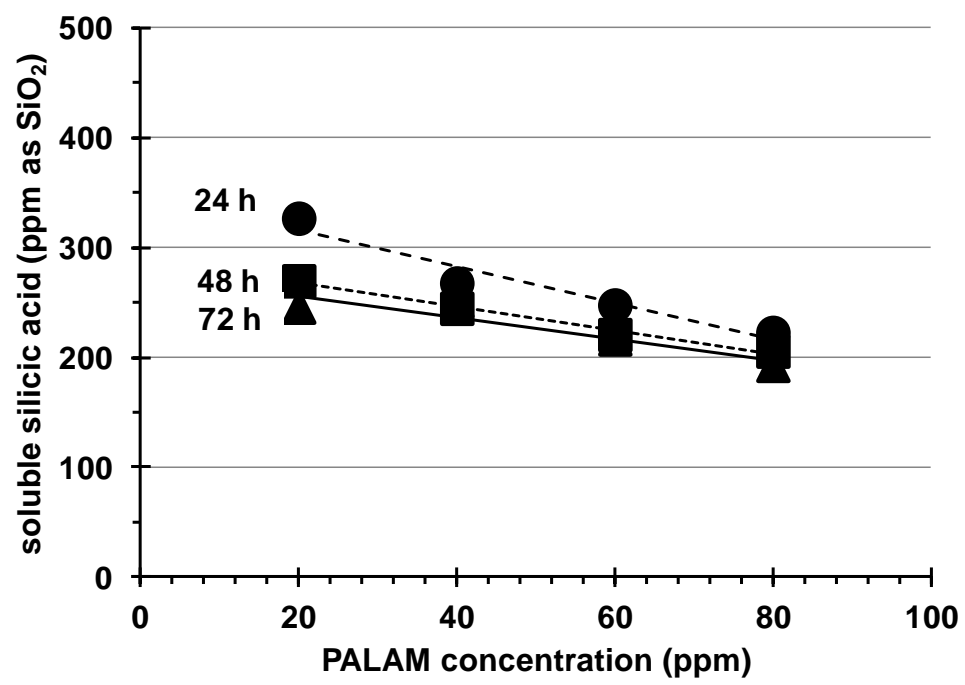

Figure 5. Reduction in inhibitory activity upon PALAM concentration increase.

It is important to note, however, that the silicic acid values at all PALAM concentrations and at the three sampling times are consistently higher than those for the control. Moreover, the drop in inhibitory activity as PALAM concentration increases can be explained on the basis of inhibitor entrapment in the forming colloidal silica particles. This has been observed before on several occasions [46,47] and it is due to the strong hydrogen bonding and ionic interactions between the positively charged PALAM and the negatively charged silica surfaces.

Based on these "long-term" results, we decided to further study the silica inhibition event at its early stages, during the first 8 hours. For this, we selected the PALAM dosages 20 and $40 \mathrm{ppm}$. These results are presented in Table 2 and plotted in Figure 6.

Silicic acid polymerizes to yield amorphous silica at $\mathrm{pH}=7$ at a fairly fast rate. For example, in the absence of inhibitors $409 \mathrm{ppm}$ silicic acid remain soluble after the first hour. The effect of inhibitors is not significant during the first hours of silicification, however, it becomes visible after the $4^{\text {th }}$ hour. After 8 hours, the difference in silicic acid levels between the control and the PALAM-containing solutions is obvious. Specifically, at $20 \mathrm{ppm}$ PALAM $123 \mathrm{ppm}$ silicic acid remain soluble, whereas at $40 \mathrm{ppm}$ PALAM 51 ppm silicic acid remain soluble. 
Table 2. Silica inhibition measurements with PALAM at concentrations 20 and $40 \mathrm{ppm}$ in short-term experiments ( 8 hours).

\begin{tabular}{cccc}
\hline \multirow{2}{*}{ Time (hours) } & \multicolumn{3}{c}{ PALAM concentration (in ppm) } \\
\cline { 2 - 4 } & Control & $\mathbf{2 0}$ & $\mathbf{4 0}$ \\
\hline 1 & 409 & 413 & 381 \\
2 & 378 & 378 & 330 \\
3 & 342 & 355 & 326 \\
4 & 330 & 378 & 311 \\
5 & 297 & 363 & 301 \\
6 & 252 & 345 & 267 \\
7 & 246 & 349 & 270 \\
8 & 224 & 347 & 275 \\
\hline
\end{tabular}

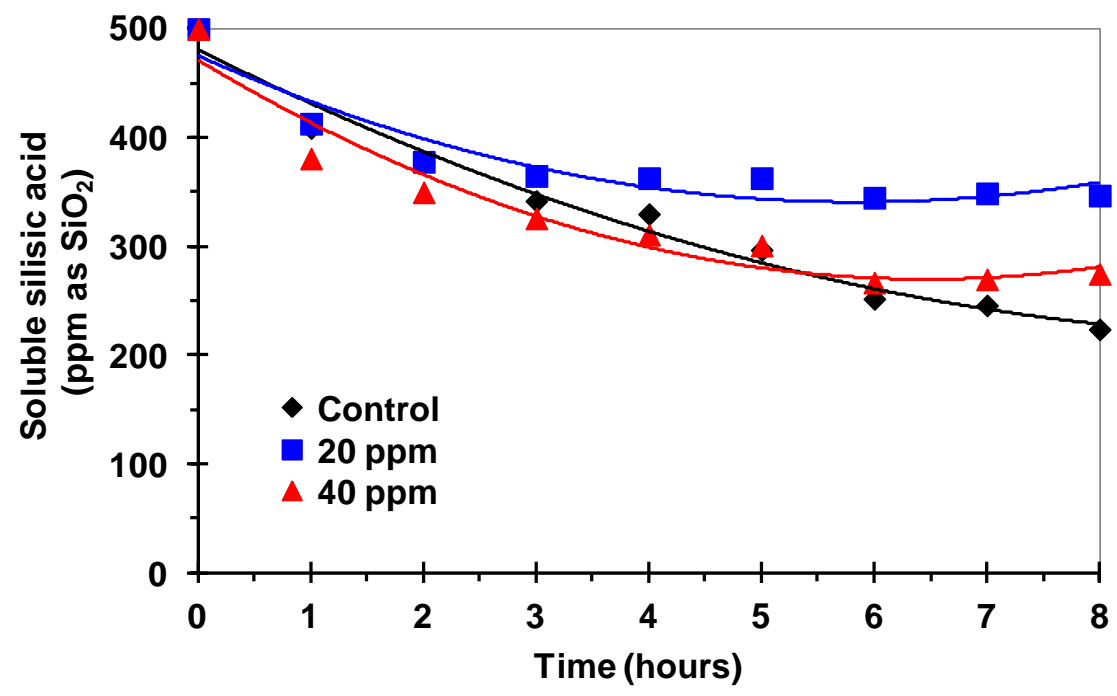

Figure 6. Silica inhibitory activity of PALAM in short-term experiments (8 hours).

\section{Inhibitory activity results of PALAM with co-inhibitors}

In the presence of PALAM amorphous "fluffy" silica precipitates are observed. As mentioned above, these are formed due to the ability of the cationic PALAM to coagulate the formed anionic silica particles that is unable to inhibit. In order to "relieve" the excessive polycationic charge that may induce silica flocculation, we thought of using a second anionic polymer, mentioned as the co-inhibitor, in hope that it will partially neutralize the positively charged primary amine groups. We evaluated three co-inhibitors, 
namely CMI, PAM-co-AA, and PCH (their structures are shown in Figure 3). The "longterm" results (3 days) are shown in Table 3 and plotted in Figure 7.

Table 3. Silica inhibition measurements with 20 ppm PALAM and its blend with CMI (20 ppm), PAMco-AA (20 ppm), and PCH (40 ppm).

Inhibitor Blend Composition

\begin{tabular}{cccccc}
$\begin{array}{c}\text { Time } \\
\text { (hours) }\end{array}$ & control & $\begin{array}{c}\text { 20 ppm } \\
\text { PALAM }\end{array}$ & $\begin{array}{c}\text { 20 ppm PALAM } \\
+ \text { 20 ppm CMI }\end{array}$ & $\begin{array}{c}\text { 20 ppm PALAM } \\
+ \text { 20 ppm PAM-co- }\end{array}$ & $\begin{array}{c}\text { 20 ppm PALAM } \\
\text { + 40 ppm PCH }\end{array}$ \\
\hline 24 & 202 & 336 & 274 & 281 & 326 \\
48 & 179 & 286 & 195 & 193 & 254 \\
72 & 160 & 246 & 184 & 179 & 238 \\
\hline
\end{tabular}

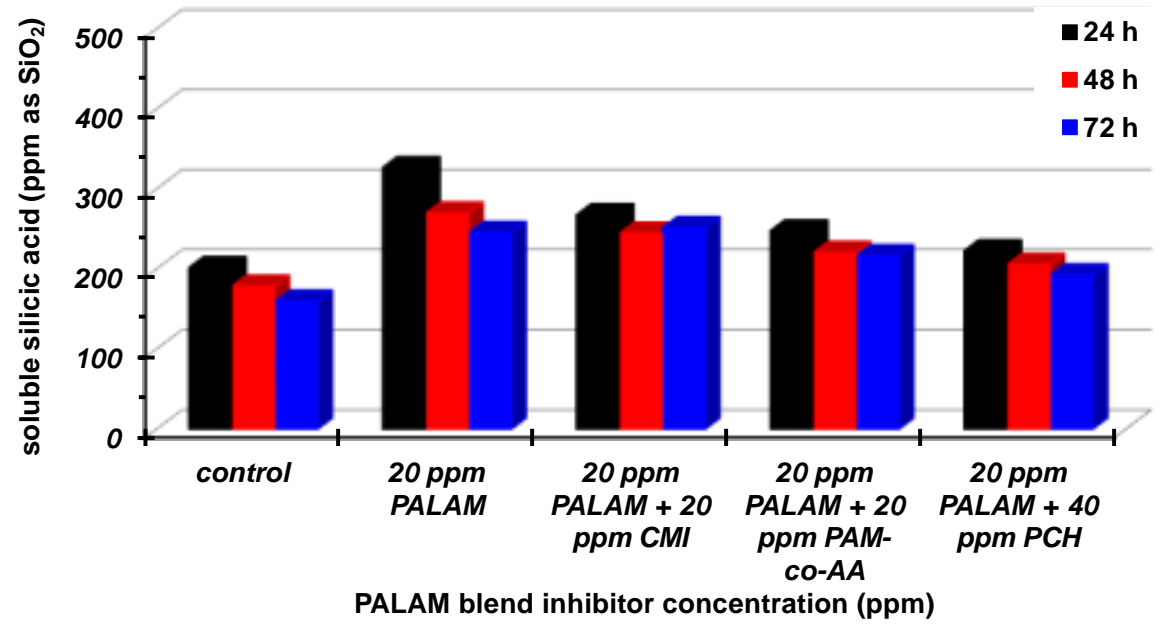

Figure 7. Silica inhibition measurements with $20 \mathrm{ppm}$ PALAM and its blend with CMI (20 ppm), PAM-co-AA (20 ppm), and PCH (40 ppm).

Upon testing blends of PALAM in "long-term" experiments (at a constant concentration of $20 \mathrm{ppm}$ ) and a variety of anionic co-inhibitors, we observed that the inhibitory activity of PALAM is dramatically affected, but it still is slightly above the "control". These results prove unequivocally that the amine cationic groups on the PALAM backbone are essential for silica scale inhibition.

As before, we also studied the silica inhibition event during its early stages ( 8 hours) in the presence of two blends: 20 ppm PALAM + 20 ppm CMI, and 20 ppm PALAM + $60 \mathrm{ppm}$ PCH. These results are given in Table 4 and Figure 8.

These "short-term" results confirm those obtained during the 3 -day period (Table 3 , Figure 7). CMI (20 ppm) shows a minor effect for the first 4 hours, but this is statistically 
insignificant. PCH $(60 \mathrm{ppm})$ induces a profound effect on the inhibitory activity of PALAM, essentially reducing it to the control levels.

Table 4. "Short-term" silica inhibition measurements at a constant PALAM concentration (20 ppm) and its blends with CMI (20 ppm) and PCH (60 ppm).

\begin{tabular}{ccccc}
\hline \multirow{2}{*}{ Time (hours) } & \multicolumn{4}{c}{ Inhibitor Blend Composition } \\
\cline { 2 - 5 } & control & 20 ppm PALAM & $\begin{array}{c}\text { 20 ppm PALAM } \\
+\mathbf{2 0} \text { ppm CMI }\end{array}$ & $\begin{array}{c}\text { 20 ppm PALAM } \\
+\mathbf{6 0} \text { ppm PCH }\end{array}$ \\
\hline 1 & 409 & 413 & 435 & 413 \\
2 & 378 & 378 & 410 & 404 \\
3 & 342 & 355 & 393 & 388 \\
4 & 330 & 378 & 403 & 370 \\
5 & 297 & 363 & 397 & 355 \\
6 & 252 & 345 & 378 & 358 \\
7 & 246 & 349 & 347 & 356 \\
8 & 224 & 347 & 333 & 345 \\
\hline
\end{tabular}

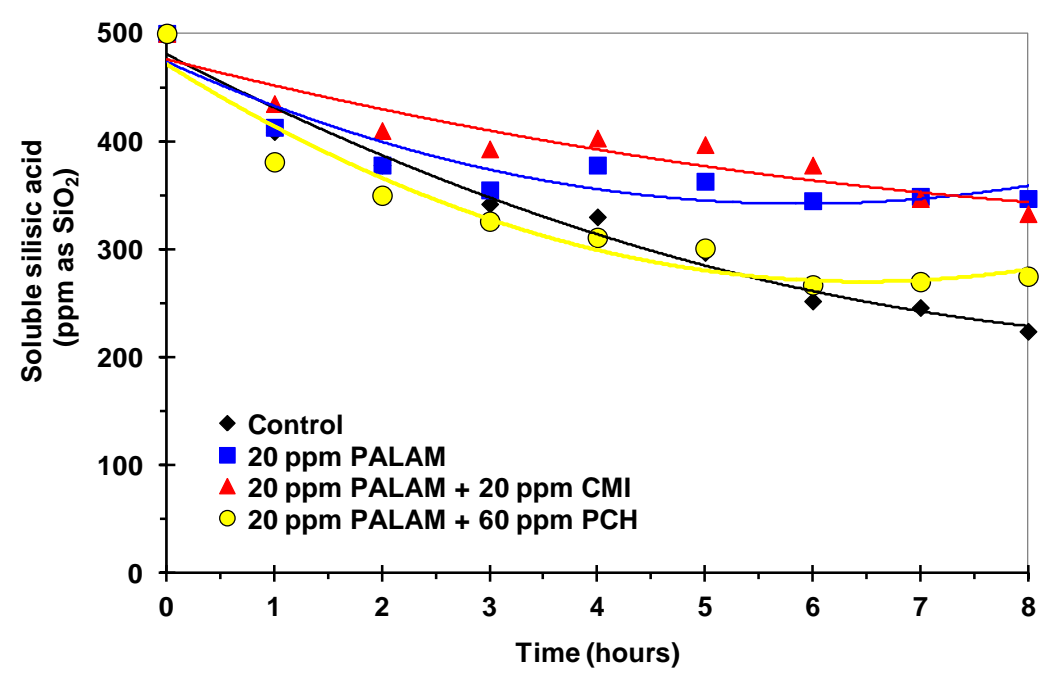

Figure 8. Silica inhibition measurements ( 8 hours) with PALAM (20 ppm) and blends with CMI (20 ppm) and PCH (60 ppm).

\section{Conclusions}

In this paper we reported the inhibitory efficiency of polyallylamine hydrochloride (PALAM) and its multifunctional synergistic mixtures on silica scale formation. The cationic charge on the PALAM backbone appears to be detrimental to its inhibitory activity. In an effort to "relieve" the excessive cationic charge on the PALAM backbone we used 
secondary, anionic polymer add-ons (co-inhibitors), such as PAM-co-AA, PCH and CMI. However, it was observed that all these co-inhibitors caused reduction in PALAM inhibitory activity.

\section{References}

1. K.D. Demadis, in Compact Heat Exchangers and Enhancement Technology for the Process Industries, Ed. R. K. Shah, Begell House Inc., New York, 2003, pp. 483-490.

2. T. R. Bott, Fouling Notebook, Rugby, Institution of Chemical Engineers, 1990.

3. J. C. Cowan and D. J. Weintritt, Water-Formed Scale Deposits, Gulf Publishing Co., Houston, TX, 1976.

4. Z. Amjad, Mineral Scale Formation and Inhibition, Plenum Press, New York, 1995.

5. T. R. Bott, Fouling of Heat Exchangers, Elsevier Science, 1995.

6. S. H. Chan, in Annual Review of heat transfer, Begell House Inc., NY, 1992, pp. 363402.

7. Z. Amjad, Science and Technology of Industrial Water Treatment, CRC Press, London, 2010.

8. K. D. Demadis, B. Yang, P. R. Young, D. L. Kouznetsov and D. G. Kelley, in Advances in Crystal Growth Inhibition Technologies, Ed. Z. Amjad, Plenum Press, New York, 2000, Ch. 16, pp. 215-234.

9. R. Sheikholeslami, Fouling of membrane and thermal units: a unified approach. Its principles, assesment, control and mitigation, Balaban Publishers; $1^{\text {st }}$ edition, 2007.

10. K. D. Demadis and E. Mavredaki, Env. Chem. Lett., 2005, 3, 127.

11. W. Harfst, Ultrapure Water, 1992, April, 59.

12. W. Den and C.-J. Wang, Sep. Purific. Technol., 2008, 59, 318.

13. R. Sheikholeslami and J. Bright, Desalination, 2002, 143, 255.

14. J. R. Drucker, D. Brodie and J. Dale, Ultarpure Water, 1988, December, 14.

15. M. Nakamura, K. Kosaka and H. Shimizu, Ultarpure Water, 1988, December, 31.

16. E. Barouda, K. D. Demadis, S. Freeman, F. Jones and M. I. Ogden, Cryst. Growth Des., 2007, 7, 321.

17. H. Ehrlich, K. D. Demadis, P. G. Koutsoukos and O. Pokrovsky, Chem. Rev., 2010, 110, 4656.

18. D. Hasson, H. Shemer and A. Sher, Ind. Eng. Chem. Res., 2011, 50, 7601.

19. S. Baraka-Lokmane, K. Sorbie, N. Poisson and N. Kohler, Pet. Sci. Technol., 2009, 27, 427.

20. A. Martinod, M. Euvrard, A. Foissy and A. Neville, Desalination, 2008, 220, 345.

21. K. D. Demadis and M. Öner, in Green Chemistry Research Trends, Ed. J. T. Pearlman, Nova Science Publishers, New York, 2009, Ch. 8, pp. 265-287.

22. K. D. Demadis, E. Neofotistou, E. Mavredaki, M. Tsiknakis, E.-M. Sarigiannidou and S. D. Katarachia, Desalination, 2005, 179, 281.

23. K. D. Demadis and E. Neofotistou, Chem. Mater., 2007, 19, 581. 
24. K. D. Demadis and E. Neofotistou, Mater. Perform., 2004, 43, no. 4, 38.

25. E. Neofotistou and K. D. Demadis, Coll. Surf. A: Physicochem. Eng. Asp., 2004, 242, 213.

26. E. Neofotistou and K.D. Demadis, Desalination, 2004, 167, 257.

27. K. D. Demadis, Power, 2004, 148, no. 6, 19.

28. K. D. Demadis, J. Chem. Technol. Biotechnol., 2005, 80, 630.

29. E. Mavredaki, E. Neofotistou and K. D. Demadis, Ind. Engin. Chem. Res., 2005, 44, 7019.

30. K. D. Demadis and E. Mavredaki, Env. Chem. Lett., 2005, 3, 127.

31. K. D. Demadis and A. Stathoulopoulou, Mater. Perform., 2005, 45, no. 1, 40.

32. K. D. Demadis, E. Mavredaki, A. Stathoulopoulou, E. Neofotistou and C. Mantzaridis, Desalination, 2007, 213, 38.

33. K. D. Demadis and A. Stathoulopoulou, Ind. Engin. Chem. Res., 2006, 45, 4436.

34. K. D. Demadis and E. Neofotistou, Chem. Mater., 2007, 19, 581.

35. K. D. Demadis, in Desalination Research Progress, Eds. D. J. Delgado and P. Moreno, Nova Science Publishers, Inc., New York, 2008, Ch. 6, pp. 249-259.

36. M. Preari, A. Tsistraki and K. D. Demadis, in Mineral Scales in Biological and Industrial Systems, Taylor and Francis, New York, 2013, Ch. 12, pp. 215-226.

37. K. D. Demadis, M. Preari and I. Antonakaki, Pure Appl. Chem., 2014, 86, 1663.

38. K. D. Demadis and M. Preari, Des. Wat. Treat., 2015, in press.

39. M. Preari, K. Spinde, J. Lazic, E. Brunner and K. D. Demadis, J. Am. Chem. Soc., 2014, 136, 4236.

40. T. Coradin, D. Eglin and J. Livage, Spectroscopy, 2004, 18, 567.

41. G. B. Alexander, J. Am. Chem. Soc., 1953, 75, 5655.

42. V. W. Truesdale, P. J. Smith and C. J. Smith, Analyst, 1979, 897.

43. V. W. Truesdale and C. J. Smith, Analyst, 1975, 797.

44. V. W. Truesdale and C.J. Smith, Analyst, 1975, 203.

45. A. D. Eaton, L. S. Clesceri, E. W. Rice, A. E. Greenberg and M.H. Franson, in Standard Methods for Examination of Water and Wastewater, American Public Health Association, 2005.

46. K. D. Demadis, K. Pachis, A. Ketsetzi and A. Stathoulopoulou, Adv. Colloid Interf. Sci., 2009, 151, 33.

47. K. D. Demadis, A. Ketsetzi, K. Pachis and V. M. Ramos, Biomacromolecules, 2008, 9, 3288. 